\title{
Genetic diversity of Piracanjuba populations in fish stocking programs in the Tietê River, Brazil
}

\section{Diversidad genética de poblaciones de Piracanjuba del programa de repoblamiento del Río Tietê, Brasil \\ Diversidade genética de populações de Piracanjuba do programa de repovoamento do Rio Tietê, Brasil}

Nelson M Lopera-Barrero $^{1 *}$, MVZ, PhD; Silvio C A Santos $^{2}$, Biol; Pedro L Castro ${ }^{3}$, Zoot, MSc; Felipe P Souza ${ }^{l}$, MV $_{\text {, MSc; }}$ Angela R Poveda-Parra ${ }^{1}$, MVZ, PhD; Victor C F Pandolfi ${ }^{l}$, Zoot; Andrei L Yamachita ${ }^{1}$, Zoot; Angela M Urrea-Rojas ${ }^{1}$, MVZ; Diego A Rojas-Meza ${ }^{4}$, Zoot, MSc; Ricardo P Ribeiro ${ }^{3}$, Zoot, PhD.

${ }^{1}$ Núcleo de Estudo e Pesquisa em Aquicultura e Genética (NEPAG), Departamento de Zootecnia, Programa de Pós-Graduação em Ciência Animal, Universidade Estadual de Londrina (UEL), Londrina, Paraná, Brasil.

${ }^{2}$ Hidrelétrica AES Tietê - Promissão, São Paulo, Brasil.

${ }^{3}$ Núcleo de Pesquisa Peixegen, Departamento de Zootecnia, Programa de Pós-Graduação em Zootecnia, Universidade Estadual de Maringá (UEM), Maringá, Paraná, Brasil.

${ }^{4}$ Faculdade de Ciências Agrárias e Veterinárias, Universidade Estadual Paulista (UNESP), Jaboticabal, São Paulo, Brasil.

(Received: January 25, 2017; accepted: October 12, 2018)

doi: 10.17533/udea.rccp.v32n2a07

\begin{abstract}
Background: Piracanjuba (Brycon orbignyanus) is a fish species highly affected by anthropogenic actions such as overfishing, water pollution, and hydroelectric developments. This species is currently considered in danger of extinction. Objective: To analyze the genetic diversity of a natural population (NP) and two captive broodstocks (SA and SB) of B. orbignyanus. Methods: Samples of caudal fins (NP: 24, SA: 30, and SB: 30) were collected. DNA was extracted and amplified for six RAPD primers and four microsatellite loci. Results: Sixty polymorphic fragments and 17 microsatellite alleles were detected. High intrapopulation heterozygosity (NP: 0.692, SA: 0.724, and SB: 0.686) was observed. Thirty-eight fragments and six alleles were shared among NP, SA, and SB. The F IS and Shannon's Index of diversity revealed a lack of inbreeding within groups. AMOVA analyses and $\mathrm{F}_{\mathrm{ST}}$ indicated very high (NP vs $\mathrm{SA}$ and $\mathrm{SB}$ ) and small (SA vs SB) genetic differentiation, confirmed by genetic distance and identity, number of migrants and a dendrogram, which revealed the formation of two

a To cite this article: Lopera-Barrero NM, Santos SCA, Castro PL, Souza FP, Poveda-Parra AR, Pandolfi VCF, Yamachita AL, Urrea-Rojas AM, Rojas-Meza DA, Ribeiro RP. Genetic diversity of Piracanjuba populations in fish stocking programs in the Tietê River, Brazil. Rev Colomb Cienc Pecu 2019; 32(2):139-149.

* Corresponding author: Nelson M Lopera-Barrero. Núcleo de Estudo e Pesquisa em Aquicultura e Genética (NEPAG), Departamento de Zootecnia, Programa de Pós-Graduação em Ciência Animal, Universidade Estadual de Londrina (UEL). Rod. Celso Garcia Cid, PR 445, km 380 - Campus Universitário - CEP: 86051-980 - Londrina - PR - Brazil. E-mail: nmlopera@uel.br
\end{abstract}


genetic groups. Conclusions: The two marker types showed similar variability. The groups have adequate genetic variability, with high differentiation between NP and SA-SB, and similarity between broodstocks.

Key words: aquaculture, Brycon orbignyanus, genetic conservation, microsatellites, RAPD.

\section{Resumen}

Antecedentes: Piracanjuba (Brycon orbignyanus) es una especie de pez fuertemente impactada por acciones antrópicas como sobrepesca, contaminación del agua y proyectos hidroeléctricos. Esta especie está considerada en peligro de extinción. Objetivo: Analizar la diversidad genética de una población natural (NP) y de dos lotes de reproductores (SA y SB) de B. orbignyanus en cautiverio. Métodos: Se colectaron 84 muestras de aleta caudal (NP: 24, SA: 30 y SB: 30). El ADN fue extraído y amplificado para seis cebadores RAPD y cuatro loci microsatélites. Resultados: Se obtuvieron 60 fragmentos polimórficos y 17 alelos microsatélites. Se observó alta heterocigosidad intra-poblacional (NP: 0,692; SA: 0,724 y SB: 0,686). Treinta y ocho fragmentos y seis alelos fueron compartidos entre NP, SA y SB. Los valores de $\mathrm{F}_{\mathrm{IS}} \mathrm{e}$ índice de Shannon mostraron ausencia de endogamia entre los grupos. Los análisis de ANOVA y $\mathrm{F}_{\mathrm{ST}}$ indicaron alta (NP vs SA y SB) y pequeña (SA vs SB) diferenciación genética; resultados confirmados por la distancia e identidad genética, número de migrantes y dendograma, evidenciando la formación de dos grupos genéticos. Conclusiones: Los grupos poseen adecuada variabilidad genética, con alta diferenciación entre NP vs SA-SB y similitud entre los lotes de reproductores.

Palabras clave: acuicultura, Brycon orbignyanus, conservación genética, microsatélites, RAPD.

\section{Resumo}

Antecedentes: Piracanjuba (Brycon orbignyanus) é uma espécie peixe fortemente impactada por ações antrópicas como sobrepesca, poluição e construção de hidrelétricas. Atualmente, essa espécie engloba a lista de peixes que correm perigo de extinção. Objetivo: Analisar a diversidade genética de uma população natural (NP) e de dois estoques de reprodutores em cativeiro (SA e SB) de B. orbignyanus. Métodos: Foram coletadas amostras de nadadeira caudal de 84 indivíduos (NP: 24, SA: 30 e SB: 30). O DNA foi extraido e amplificado para seis primers RAPD e quatro loci microssatélites. Resultados: Foram obtidos 60 fragmentos polimórficos e 17 alelos microssatélites. Foi observada uma alta heterozigosidade intra-populacional (NP: 0,692; SA: 0,724 e SB: 0,686). Trinta e oito fragmentos e seis alelos foram compartilhados entre NP, SA e SB. Os valores de $\mathrm{F}_{\text {IS }}$ e índice de Shannon demonstraram ausência de endogamia entre os grupos. As análises de AMOVA e $\mathrm{F}_{\mathrm{ST}}$ indicaram alta (NP vs SA e SB) e pequena (SA vs SB) diferenciação genética, resultados confirmados pela distância e identidade genética, número de migrantes e dendrograma, que evidenciaram a formação de dois grupamentos genéticos. Conclusões: Os grupos possuem adequada variabilidade genética, com alta diferenciação entre NP e SA-SB e similaridade entre os estoques de reprodutores.

Palabras-chaves: aquicultura, Brycon orbignyanus, conservação genética, microssatélites, RAPD.

\section{Introduction}

The Tietê River has high social and economic significance for the state of São Paulo, Brazil, because it is an important source of water, food, and labor for river communities (Oliveira, 2014). The river is known for environmental problems, mainly caused by the chaotic growth of its bordering cities, and its fish biodiversity has been significantly affected by the construction of hydroelectric plants (Pereira, 2014).

One of the fish species in the Tietê River is Piracanjuba (Brycon orbignyanus), a rheophilic species native to the Plata river basin, with great economic importance (Antunes et al., 2010). This species undertakes trophic and long reproductive migrations, and prefers habitats with continuous water flow (Lima et al., 2003). Since Piracanjuba are omnivorous and highly sensitive to environmental changes, especially anthropogenic activities (e.g., destruction of riverside habitats, overfishing, and damming), natural populations of this species have decreased during recent decades (Agostinho et al., 2008).

Damming is the construction of a physical barrier that isolates populations and impairs the upstream migration of most fish species, including Piracanjuba, with marked consequences for intrapopulation genetic 
variability (Lopera-Barrero et al., 2010). Although stocking programs have been developed to mitigate these effects, research on their efficiency and genetic and environmental impacts is urgently required (Povh et al., 2010).

Inadequate management of broodstocks and lack of monitoring of both natural populations and specimens released in the rivers through stocking programs may trigger future loss of genetic diversity, generating homogenization (Satake and Araki, 2012). Consequently, correct stocking management -considering the biological characteristics of each species- is crucial for the production of quality fingerlings (Reynalte-Tataje et al., 2013) and this, naturally, includes the maintenance of genetic variability (Lopera-Barrero et al., 2014).

The use of molecular markers to assess the genetic composition of fish populations is an important strategy for measuring the genetic variability among specimens. Recent studies have shown that the use of RAPD (Random Amplified Polymorphic DNA) and microsatellites may provide important information on population genetics in fish culture stations and in natural environments, and these markers are widely used for analysis of genetic variability in several species (Ashikaga et al., 2015; Lopera-Barrero et al., 2016; Ribeiro et al., 2016; Coimbra et al., 2017; Souza et al., 2018).

Therefore, the present study aimed to analyze, for the first time, the genetic diversity of a natural population and two broodstocks of $B$. orbignyanus used in the stocking program of the Tietê River, Sao Paulo, Brazil, using RAPD and microsatellite markers.

\section{Materials and methods}

Samples of caudal fins were retrieved from a natural population (NP, 24 samples) of $B$. orbignyanus in the Nova Avanhandava reservoir of Rio Tietê $\left(21^{\circ} 07^{\prime} 05^{\prime \prime} \mathrm{S}, 50^{\circ} 12^{\prime} 02^{\prime \prime} \mathrm{W}\right)$ and from two broodstocks in fish culture stations
(Stock A $=$ SA and Stock B $=$ SB, 30 samples each) used in the stocking program by the energy company AES Brasil (2117'52'S, 4947'20'W). Stocks from fish culture stations were established using fish from the Paraná River captured in 2000, with the addition of new specimens from the Tietê River (one of the main tributaries of the Paraná River), state of São Paulo, Brazil. Methodologies employed were approved by the Committee for Ethics in the Use of Animals of Universidade Estadual de Londrina (CEUA UEL nº 17156.2012 .50 ).

DNA was extracted according to the $\mathrm{NaCl}$ extraction protocol of Lopera-Barrero et al. (2008) and quantified in a spectrophotometer (UV 1601; Shimadzu, Columbia, MD, USA) with $260 \mathrm{~nm}$ absorbance. For RAPD markers, genomic DNA was amplified in a $15 \mu \mathrm{L}$ reaction volume containing $1 \times$ Tris- $\mathrm{KCl}, 2.5 \mathrm{mM}$ of $\mathrm{MgCl}_{2}, 0.46 \mu \mathrm{M}$ of primer, $0.2 \mathrm{mM}$ of each dNTP, 1 unit of Platinum Taq DNA Polymerase (Invitrogen, USA) and $10 \mathrm{ng}$ of target DNA. DNA was denatured at $94{ }^{\circ} \mathrm{C}$ for $4 \mathrm{~min}$, followed by 40 cycles, each comprising $1 \mathrm{~min}$ denaturation at $94{ }^{\circ} \mathrm{C}, 90 \mathrm{~s}$ annealing at $40{ }^{\circ} \mathrm{C}$, and 2 min extension at $72{ }^{\circ} \mathrm{C}$, with a final extension at $72{ }^{\circ} \mathrm{C}$ for $5 \mathrm{~min}$. RAPD reactions were performed in a thermocycler (Eppendorf Mastercycler Gradient). The amplification of 60 decamer primers from kits OPA, OPX and OPW (Operon Technologies Ltd) was assessed and those primers with the best definition and reproducibility were used for further analyses (Table 1).

For microsatellite markers, DNA was amplified in a $20 \mu \mathrm{L}$ reaction volume containing $1 \times$ Tris- $\mathrm{KCl}, 2.0$ $\mathrm{mM}$ of $\mathrm{MgCl}_{2}, 0.8 \mu \mathrm{M}$ of each primer (Forward and Reverse), $0.4 \mathrm{mM}$ of each dNTP, 1 unit of Platinum Taq DNA Polymerase and $20 \mathrm{ng}$ of target DNA. DNA was initially denatured at $94{ }^{\circ} \mathrm{C}$ for $4 \mathrm{~min}$, followed by 30 cycles, each comprising $30 \mathrm{~s}$ denaturation at $94{ }^{\circ} \mathrm{C}, 30 \mathrm{~s}$ annealing with variable temperature for each primer, $1 \mathrm{~min}$ extension at $72{ }^{\circ} \mathrm{C}$, and a final extension at $72{ }^{\circ} \mathrm{C}$ for $10 \mathrm{~min}$. Four loci, described by Barroso et al. (2003) for Brycon opalinus, were amplified (Table 1). 
Table 1. Characterization of RAPD (Random Amplified Polymorphic DNA) primers and microsatellite loci.

\begin{tabular}{|c|c|c|c|c|c|c|c|c|}
\hline \multicolumn{9}{|c|}{ RAPD } \\
\hline Primers & $\% G C$ & \multicolumn{2}{|c|}{ Primer sequence $5^{\prime}-3^{\prime}$} & \multicolumn{2}{|c|}{$N F$} & \multicolumn{3}{|c|}{$T(b p)$} \\
\hline OPW02 & 70 & & CG CCAA & \multicolumn{2}{|l|}{11} & \multicolumn{3}{|c|}{$320-1500$} \\
\hline OPW03 & 70 & & SG AGT G & \multicolumn{2}{|c|}{15} & \multicolumn{3}{|c|}{$250-1500$} \\
\hline OPW08 & 60 & & $\triangle \mathrm{C} \mathrm{CTC} \mathrm{T}$ & \multicolumn{2}{|c|}{05} & \multicolumn{3}{|c|}{$310-1400$} \\
\hline OPW13 & 60 & & SC GAC A & \multicolumn{2}{|c|}{08} & \multicolumn{3}{|c|}{$280-1500$} \\
\hline OPW19 & 60 & & C GCT C & \multicolumn{2}{|c|}{11} & \multicolumn{3}{|c|}{$290-1500$} \\
\hline OPX01 & 70 & & SC ACG A & \multicolumn{2}{|c|}{06} & \multicolumn{3}{|c|}{$210-1450$} \\
\hline \multicolumn{9}{|c|}{ Microsatellite } \\
\hline Locus & \multicolumn{2}{|c|}{$S R$} & \multicolumn{2}{|c|}{ Primer sequence 5'- 3' } & $\operatorname{TA}\left({ }^{\circ} \mathrm{C}\right)$ & $N A$ & & $T(b p)$ \\
\hline BoM1 & \multicolumn{4}{|c|}{$\begin{array}{c}\text { F: CCATCTCTACTTTTTGGTTCC } \\
\text { R: TGCCCAGATACAGCCC }\end{array}$} & 54 & \multicolumn{2}{|l|}{04} & $180-202$ \\
\hline BoM2 & \multicolumn{2}{|c|}{$(\mathrm{CA})_{45}$} & \multicolumn{2}{|c|}{$\begin{array}{c}\text { F: CTGGGCAGCGGAAGAG } \\
\text { R: CCCACATCTCTCCCCTTCG }\end{array}$} & 60 & \multicolumn{2}{|l|}{03} & $130-150$ \\
\hline BoM5 & $\begin{array}{r}(\mathrm{AC}) \\
\mathrm{AT}\end{array}$ & )$_{5}$ & $\begin{array}{l}\text { F: CGACCA } \\
\text { R: CTGGA }\end{array}$ & & 51 & 06 & & $90-120$ \\
\hline BoM13 & & & $\begin{array}{r}\mathrm{F}: \mathrm{CATTTCC} T \\
\mathrm{R}: \mathrm{CCCAC}\end{array}$ & & 51 & 04 & & $160-180$ \\
\hline
\end{tabular}

\%GC: percentage of guanine and cytosine; NF: number of fragments; SR: repetition sequence; TA: annealing temperature; NA: number of alleles; T: size of alleles and fragments.

Electrophoresis of RAPD fragments was performed in $1.5 \%$ agarose gels in $0.5 \times$ TBE buffer $(45 \mathrm{mM}$ Tris-Borate and $1 \mathrm{mM}$ EDTA) for $4 \mathrm{~h}$ at $70 \mathrm{~V}$. Microsatellite marker amplification products were electrophoresed in denaturing $10 \%$ polyacrylamide gels (29:1 acrylamide: bis-acrylamide; $6 \mathrm{M}$ urea), in $1 \times$ TBE buffer $(90 \mathrm{mM}$ Tris-Borate and $2 \mathrm{mM}$ EDTA) for $7 \mathrm{~h}$ at $320 \mathrm{~V}$ and $250 \mathrm{~mA}$. Silver nitrate staining was used to visualize microsatellite alleles, following a modification of the method described by Bassam et al. (1991).

The size of RAPD fragments was estimated by comparison with a $100 \mathrm{bp}$ ladder standard (Invitrogen, Carlsbad, USA). The percentage of polymorphic fragments was calculated with PopGene 1.31 (Yeh et al., 1999), and the program TFPGA 1.3 (Miller, 1997) was used to determine Nei's genetic distance and identity measures. Arlequin 3.0 (Excoffier et al., 2005) was used to determine genetic differentiation by $F_{\mathrm{ST}}$ estimates, analysis of molecular variance, and the number of migrants per generation $(\mathrm{Nm})$. The genetic differentiation among groups was categorized as low $\left(F_{\mathrm{ST}}=0-0.05\right)$, moderate $\left(F_{\mathrm{ST}}=0.051-0.15\right)$, high $\left(F_{\mathrm{ST}}=0.151-0.25\right)$, or very high $\left(F_{\mathrm{ST}}>0.25\right)$, following Wright (1978).

Microsatellite allele sizes were estimated by comparison with a DNA ladder (Invitrogen) of 10, 50 , and $100 \mathrm{bp}$. The number of alleles, observed and expected heterozygosity, Hardy-Weinberg Equilibrium (HWE) test, number of migrants, and 
fixation index $\left(F_{\text {IS }}\right)$ were calculated for each locus using GENEPOP 4.0.6 (Rousset, 2008). Deficiency or excess of heterozygotes for loci in the HWE test was based on Fisher's exact test and calculated by the Markov chain method (Markov chain length: 100,000; dememorizations: 10,000). Shannon's genetic diversity index, allele frequency, and genetic distance and identity were calculated with PopGene 1.31 (Yeh et al., 1999). Allele richness was calculated with FSTAT 2.9.3.2 (Goudet, 2002). Analysis of genetic differentiation $\left(F_{\mathrm{ST}}\right)$ and analysis of molecular variance (AMOVA) were performed using Arlequin 3.0. A dendrogram based on Nei's genetic distance was constructed with MEGA 5.0 (Tamura et al., 2011).

\section{Results}

Sixty polymorphic RAPD fragments were retrieved, with variations between 15 (OPW03) and 5 (OPW08) fragments per primer. The largest fragments (approx. $1500 \mathrm{bp}$ ) were observed with primers OPW02, OPW03, OPW13, and OPW019, whereas the smallest fragment $(210 \mathrm{bp})$ was observed with primer OPX01. All microsatellite loci used were polymorphic and amplified consistent and reproducible alleles. Seventeen alleles were observed, varying between six (BoM5) and three (BoM2) alleles per locus, with sizes between $90 \mathrm{bp}$ (BoM5) and $202 \mathrm{bp}$ (BoM1) (Table 2).

Table 2. Frequency of RAPD (Random Amplified Polymorphic DNA) fragments and microsatellite alleles in $B$. orbignyanus populations.

\begin{tabular}{|c|c|c|c|c|c|}
\hline \multicolumn{6}{|c|}{ RAPD } \\
\hline Primer & Fragment & $P$ & $N P$ & $S A$ & $S B$ \\
\hline \multirow[t]{8}{*}{ OPW02 } & 1500 & 0.000 & 0.3745 & $0.0168^{* *}$ & -- \\
\hline & 1300 & 0.001 & 0.4102 & 0.1056 & 0.1835 \\
\hline & 1150 & 0.009 & 0.2482 & -- & 0.5528 \\
\hline & 950 & 0.010 & 0.3406 & -- & 0.1056 \\
\hline & 700 & 0.043 & 0.3084 & -- & 0.1244 \\
\hline & 580 & 0.000 & 0.7915 & 0.2254 & -- \\
\hline & 450 & 0.000 & 0.6388 & $0.0513^{* *}$ & $0.0168^{* *}$ \\
\hline & 320 & 0.000 & 0.3084 & $0.0339^{* *}$ & -- \\
\hline \multirow[t]{12}{*}{ OPW03 } & 1500 & 0.000 & 0.6985 & 0.1056 & -- \\
\hline & 1300 & 0.010 & $0.1210^{\mathrm{EF}}$ & -- & -- \\
\hline & 1290 & 0.042 & 0.2023 & -- & $0.0513^{* *}$ \\
\hline & 1250 & 0.020 & 0.2023 & 0.4523 & -- \\
\hline & 1200 & 0.020 & $0.0955^{\star *}$ & 0.3169 & -- \\
\hline & 1090 & 0.002 & 0.3258 & $0.0691^{* *}$ & $0.0691^{* *}$ \\
\hline & 1010 & 0.000 & 0.5233 & $0.0339^{* *}$ & 0.1633 \\
\hline & 850 & 0.043 & 0.2313 & $0.0691^{* *}$ & -- \\
\hline & 600 & 0.010 & 0.1743 & 0.4523 & 0.7418 \\
\hline & 550 & 0.000 & 0.3258 & $0.0513^{* *}$ & --- \\
\hline & 410 & 0.000 & 0.4359 & -- & $0.0168^{* *}$ \\
\hline & 250 & 0.000 & $0.2929^{\mathrm{EF}}$ & -- & -- \\
\hline \multirow[t]{3}{*}{ OPW08 } & 1300 & 0.000 & 0.1403 & $1.0000^{*}$ & 0.7418 \\
\hline & 1000 & 0.000 & 0.2777 & 0.7418 & 0.5528 \\
\hline & 700 & 0.000 & $0.5337^{\mathrm{EF}}$ & -- & -- \\
\hline
\end{tabular}




\begin{tabular}{|c|c|c|c|c|c|}
\hline \multicolumn{6}{|c|}{ RAPD } \\
\hline Primer & Fragment & $P$ & $N P$ & $S A$ & $S B$ \\
\hline & 650 & 0.000 & $0.6388^{\mathrm{EF}}$ & -- & -- \\
\hline & 590 & 0.013 & $0.1153^{\mathrm{EF}}$ & -- & -- \\
\hline & 510 & 0.000 & $0.5830^{\mathrm{EF}}$ & -- & -- \\
\hline & 480 & 0.013 & $0.1153^{\mathrm{EF}}$ & -- & -- \\
\hline & 390 & 0.000 & $0.4892^{\mathrm{EF}}$ & -- & -- \\
\hline & 310 & 0.000 & $0.3406^{\mathrm{EF}}$ & -- & -- \\
\hline \multirow[t]{12}{*}{ OPW13 } & 1340 & 0.002 & 0.3876 & 0.8174 & 0.8174 \\
\hline & 1240 & 0.001 & 0.3545 & 0.8174 & 0.8174 \\
\hline & 1150 & 0.000 & 0.2094 & 0.5918 & 0.7418 \\
\hline & 1000 & 0.005 & 0.4599 & -- & 0.1633 \\
\hline & 900 & 0.001 & 0.2929 & -- & $0.0513^{* *}$ \\
\hline & 790 & 0.000 & 0.7113 & 0.2042 & $0.0871^{* *}$ \\
\hline & 690 & 0.000 & 0.7959 & 0.3169 & 0.4226 \\
\hline & 540 & 0.000 & $0.7959 \mathrm{EF}$ & -- & -- \\
\hline & 490 & 0.000 & $0.3545^{\mathrm{EF}}$ & -- & -- \\
\hline & 410 & 0.000 & $1.0000^{\star E F}$ & -- & -- \\
\hline & 340 & 0.001 & $0.1584^{\mathrm{EF}}$ & -- & -- \\
\hline & 280 & 0.002 & $0.1584^{\mathrm{EF}}$ & -- & -- \\
\hline \multirow[t]{10}{*}{ OPW19 } & 1500 & 0.000 & 0.7113 & $0.0513^{* *}$ & -- \\
\hline & 1350 & 0.007 & 0.7113 & 0.3417 & 0.2472 \\
\hline & 1200 & 0.029 & $1.0000^{*}$ & 0.5528 & 0.3945 \\
\hline & 800 & 0.000 & 0.5436 & 0.1633 & 0.2472 \\
\hline & 650 & 0.000 & 0.2362 & $1.0000^{*}$ & -- \\
\hline & 600 & 0.003 & 0.3876 & -- & 0.1244 \\
\hline & 490 & 0.003 & 0.5000 & 0.1865 & $0.0339^{* *}$ \\
\hline & 400 & 0.003 & 0.2362 & $0.0339^{* *}$ & $0.0339^{* *}$ \\
\hline & 350 & 0.001 & $0.1584^{\mathrm{EF}}$ & -- & -- \\
\hline & 290 & 0.000 & $0.2362^{\mathrm{EF}}$ & -- & -- \\
\hline \multirow[t]{9}{*}{ OPX01 } & 1150 & 0.032 & 0.4483 & 0.7418 & 0.8174 \\
\hline & 900 & 0.032 & 0.5830 & - & $1.0000^{*}$ \\
\hline & 810 & 0.000 & 0.4892 & 0.1244 & 0.1633 \\
\hline & 700 & 0.000 & 1.0000 *EF & -- & -- \\
\hline & 590 & 0.000 & 1.0000 *EF & -- & -- \\
\hline & 490 & 0.000 & $0.3084^{\mathrm{EF}}$ & -- & -- \\
\hline & 390 & 0.000 & $1.0000^{* \mathrm{EF}}$ & -- & -- \\
\hline & 300 & 0.000 & $0.7915^{\mathrm{EF}}$ & -- & -- \\
\hline & 210 & 0.030 & $0.0911^{* \star E F}$ & -- & -- \\
\hline
\end{tabular}




\begin{tabular}{|c|c|c|c|c|}
\hline \multicolumn{5}{|c|}{ Microsatellite } \\
\hline Primer & Allele & $N P$ & $S A$ & $S B$ \\
\hline \multirow[t]{4}{*}{ BoM1 } & 202 & - & 0.379 & 0.433 \\
\hline & 200 & 0.500 & 0.500 & 0.500 \\
\hline & 190 & - & 0.121 & 0.067 \\
\hline & 180 & 0.500 & - & - \\
\hline \multirow[t]{3}{*}{ BoM2 } & 150 & 0.391 & 0.383 & 0.333 \\
\hline & 140 & - & 0.617 & 0.667 \\
\hline & 130 & 0.609 & - & - \\
\hline \multirow[t]{6}{*}{ BoM5 } & 120 & 0.150 & - & - \\
\hline & 110 & 0.125 & - & - \\
\hline & 100 & 0.400 & 0.400 & 0.448 \\
\hline & 98 & - & 0.200 & 0.259 \\
\hline & 95 & - & 0.400 & 0.293 \\
\hline & 90 & 0.325 & - & - \\
\hline \multirow[t]{4}{*}{ BoM13 } & 180 & 0.176 & - & - \\
\hline & 170 & 0.118 & 0.133 & 0.217 \\
\hline & 165 & 0.323 & 0.467 & 0.483 \\
\hline & 160 & 0.382 & 0.400 & 0.300 \\
\hline
\end{tabular}

NP: natural population; SA: Stock A; SB: Stock B; *limiting fragments; **low frequency fragments; EF: exclusive fragment.

There were significant differences $(\mathrm{p}<0.05)$ in the number of RAPD fragments observed in NP (60 fragments), SA (29), and SB (28). Five limiting fragments (with frequency 1.000) and only two fragments at low frequency (less than 0.100) were observed in NP, revealing high genetic variability. Compared to NP, the stock populations showed fewer limiting fragments (SA: 2 and SB: 1), and more lowfrequency fragments (SA: 9 and SB: 8), suggesting genetic similarity between SA and SB. Only NP showed exclusive fragments (22), indicating genetic differentiation between natural and stock populations.

For microsatellite markers, there was no difference $(\mathrm{p}<0.01)$ between $(H \mathrm{o})$ and expected $(H e)$ heterozygosity among the populations. High heterozygosity rates in the three populations (SA: average 0.724; SB: 0.686; NP: 0.692) and nonsignificant HWE revealed an adequate intrapopulation genetic variability. The Shannon Index showed a similar trend of high genetic diversity within populations, with the highest diversity observed in NP (0.523). After Bonferroni correction, allele richness $\left(A_{R}\right)$ was similar among the groups: 5.5 for NP and SB, and 6 for SA. Negative rates of the inbreeding coefficient $\left(F_{\text {IS }}\right)$ were found in the three populations (Table 3$)$.

Table 3. Statistics of four microsatellite loci used for $B$. orbignyanus populations.

\begin{tabular}{cccc}
\hline Genetic indices & NP & SA & SB \\
\hline Ho & $0.692^{* *}$ & $0.724^{* *}$ & $0.686^{* *}$ \\
He & 0.587 & 0.609 & 0.579 \\
$\mathrm{~F}_{\mathrm{IS}}$ & -0.221 & -0.292 & -0.235 \\
$\mathrm{H}^{\prime}$ & 0.523 & 0.313 & 0.296 \\
$\mathrm{HWE}$ & $\mathrm{NS}$ & $\mathrm{NS}$ & $\mathrm{NS}$ \\
$\mathrm{A}_{\mathrm{R}}$ & 5.5 & 6.0 & 5.5 \\
\hline
\end{tabular}

NP: natural population; SA: Stock A; SB: Stock B; $H_{\mathrm{O}}$ : observed heterozygosity; $H_{\mathrm{E}}$ : expected heterozygosity; $F_{I S}$ : Fixation Index; $H^{\prime}$ : Shannon Index; HWE: Hardy-Weinberg Equilibrium test; $\mathrm{N}_{\mathrm{A}}$ : number of alleles per locus; $A_{R}$ : allele richness; NS: not significant; ${ }^{* *} p<0.01$ after Bonferroni correction (nominal $\alpha=0.05$ ). 
Table 4. Analysis of molecular variance (AMOVA) for three B. orbignyanus populations.

\begin{tabular}{|c|c|c|c|c|c|c|}
\hline \multirow{2}{*}{ Marker } & \multicolumn{3}{|c|}{ Between populations } & \multicolumn{3}{|c|}{ Within populations } \\
\hline & NP vs SA & NP vs SB & SA vs SB & NP vs SA & NP vs SB & SA vs \\
\hline \multicolumn{7}{|l|}{ RAPD } \\
\hline Sum of squares & 223.968 & 248.958 & 30.05 & 561.96 & 537.3150 & 451.167 \\
\hline Components of variance & 7.886 & 8.827 & 0.742 & 10.603 & 10.13801 & 7.778 \\
\hline Percentage of variation & 42.65 & 46.54 & 4.71 & 57.35 & 53.46 & 95.29 \\
\hline \multicolumn{7}{|l|}{ Microsatellite } \\
\hline Sum of squares & 14.68 & 16.115 & 0.667 & 52.24 & 51.5450 & 135.167 \\
\hline Components of variance & 0.272 & 0.299 & 0.0079 & 0.502 & 0.49562 & 1.15346 \\
\hline Percentage of variation & 35.15 & 37.70 & 0.70 & 64.85 & 62.30 & 99.3 \\
\hline
\end{tabular}

NP: natural population; SA: Stock A; SB: Stock B.

AMOVA revealed the greatest proportion of genetic variation in the populations (average 68.7\% for RAPD and $75.48 \%$ for microsatellites). For Stocks $\mathrm{A}$ and $\mathrm{B}$, intrapopulation variation accounted for 95.29 and $99.3 \%$ of the total genetic variation for RAPD and microsatellites, respectively (Table 4).
The UPGMA dendrogram was constructed using Nei's distance (Figure 1) based on the frequency and distribution of fragments and alleles. The distance and genetic identity, AMOVA, and $\mathrm{F}_{\mathrm{ST}}$ and $\mathrm{Nm}$ values among the populations are given in Table 5 .

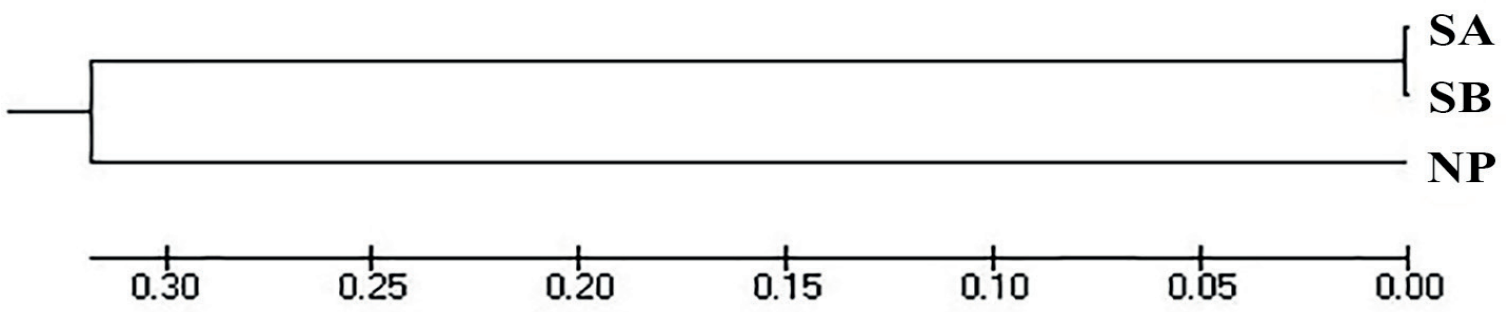

Figure 1. Dendrogram of three B. orbignyanus populations: Natural population (NP); Stock A (SA); Stock B (SB).

Table 5. Summary of the statistics used for RAPD (Random Amplified Polymorphic DNA) and microsatellite data from three B. orbignyanus populations.

\begin{tabular}{llllllllll}
\hline & RAPD & \multicolumn{9}{c}{ Microsatellite } \\
\hline & $F_{S T}$ & Wright & GI/GD & Nm & $F_{S T}$ & Wright & GI/GD & Nm \\
\hline NP vs SA & 0.426 & High & $0.266 / 0.766$ & 1.58 & 0.351 & High & $0.539 / 0.618$ & 1.50 \\
NP vs SB & 0.465 & High & $0.286 / 0.751$ & 1.45 & 0.377 & High & $0.520 / 0.654$ & 1.42 & 50.67 \\
SA vs SB & 0.047 & Low & $0.984 / 0.016$ & 12.03 & 0.007 & Low & $0.998 / 0.002$ & 5 \\
\hline
\end{tabular}

$F_{\text {ST: }}$ Fixation Index; Wright: Wright's genetic differentiation (1978); GI: genetic identity; GD: genetic distance; Nm: number of migrants, NP: natural population; SA: Stock A; SB: Stock B. 


\section{Discussion}

Thirty-eight out of 60 polymorphic fragments (RAPD) and 6 out of 17 alleles (microsatellites) were shared by the three populations. According to Caballero et al. (2010), allele richness characterizes the number of segregated alleles in a specific population. The present study revealed a homogeneous distribution of alleles among populations and confirmed allele sharing between stocks and natural populations. Further, the high observed and expected heterozygosity among populations is similar to those found by Lopera-Barrero et al. (2014) who detected high $H o$ rates, varying between 0.823 and 0.900 , in $B$. orbignyanus. The number of alleles found in the present study is also similar to that reported by Lopera-Barrero et al. (2014). Our results suggest that the broodstocks that supply fish for the stocking program are managed appropriately, enhancing the maintenance of the number of specimens in natural populations and avoiding bottleneck effects that would cause allele loss, increase in genetic drift, and decrease in genetic variability.

Mean negative rates of the inbreeding coefficient $\left(F_{\text {IS }}\right)$ in the three populations demonstrated lack of inbreeding and confirmed the hypothesis that populations were not affected by a bottleneck effect. The high and homogeneous heterozygosity, coupled with the negative $F_{\text {IS }}$ values, indicate correct reproductive management that has reduced the occurrence of inbreeding and maintained high genetic variability in the stocks from fish culture stations.

The two molecular marker types showed similar genetic identity and genetic distance results. Although genetic identity values in broodstocks from fish culture stations were high, they were lower than the values for NP. Similarly, genetic distance was low between stocks A and B, but high between NP and stocks A and $\mathrm{B}$, indicating low genetic similarity between NP and stocks $\mathrm{A}$ and $\mathrm{B}$. The $\mathrm{F}_{\mathrm{ST}}$ values also showed low genetic differentiation (0.047 and 0.007 for RAPD and microsatellites, respectively) between stocks from fish culture stations, and high differentiation between NP and stocks A and B. Estimations of the number of migrants $(\mathrm{Nm})$ revealed low genic flow between the natural population and stocks $\mathrm{A}$ and $\mathrm{B}$, and high genic flow between stocks from fish culture stations, for both marker types.
The dendrogram confirmed the formation of two genetic groups, one comprising the natural population and the other formed by the two stocks from the fish culture stations. In addition to describing the genetic composition and variability among populations, we have demonstrated that the two marker types showed similar results with regard to the genic structure of the groups, especially for genetic differentiation and similarity.

Utilizing microsatellite markers, Ashikaga et al. (2015) reported different levels of genetic variability in eight populations of $B$. orbignyanus from the Plata River basin (heterozygosity between 0.198 and 0.498). The authors reported that the analysis of molecular variance (AMOVA) and $F_{\mathrm{ST}}$ (mean 0.258 ) revealed structuring in different subgroups: the subgroups from the best environmental conditions had the highest rates of genetic variability.

Employing RAPD markers, Panarari-Antunes et al. (2011) analyzed B. orbignyanus from natural populations and from fish culture stations of the Paraná River and discovered high genetic distance between groups. The authors emphasize that the difference may be due to the reproductive management in fish culture stations, which makes genetic difference even more evident. This also applies to the present analysis since the observed high genetic differentiation between fish station stocks and the natural population is mainly due to the common origin of broodstocks in fish stations and the mating succession enhanced by the stocking program. In view of this, the fish culture station stocks should not be used to repopulate the natural population, since the high genetic differentiation between them may negatively affect the local genetic diversity, decrease adaptive fitness, and increase competition with native fish. In a study developed by Coimbra et al. (2017) with natural populations of Prochilodus argenteus and a stock from the restocking program in the São Francisco River, Brazil, a moderate genetic differentiation $\left(\mathrm{F}_{\mathrm{ST}}\right)$ was observed between the natural populations and the restocking stock. Coimbra et al. (2017) also stressed the genetic risk of fingerling inclusion in any of the natural populations and they recommend a more frequent participation of fish from natural populations for broodstock supply (always based on genetic analysis), thus adding new genetic variation. 
The molecular markers employed in the present study have provided efficient and satisfactory results. As RAPD markers are dominant, they do not identify heterozygotes, and highly dependent on PCR conditions (concentration of reagents and cycling times), which may limit its use. However, when RAPD markers are properly used they can provide excellent results for studying genetic variability in fish (Panarari-Antunes et al., 2011; Lopera-Barrero et al., 2016; Ribeiro et al., 2016). In contrast, microsatellites are co-dominant (they allow to identify heterozygotes) and have a high degree of polymorphism, allowing a more detailed analysis of the variation among populations. Our results demonstrate the importance of using both marker types together, since, even with different molecular features, the two markers gave very similar results.

Adequate genetic variability has been observed in the three populations, with genetic differentiation between the natural population and stocks from fish culture stations. Shared fragments among populations may suggest the presence of specimens derived from stocking programs in the natural environment. The two different molecular techniques gave similar results with regard to the genetic variability between groups.

\section{Acknowledgments}

The authors would like to thank the 'CAPES', the 'Programa de Pós Graduação em Ciência Animal (State University of Londrina, Brazil), AES Tietê, and ANNEL.

\section{Conflicts of interest}

The authors declare they have no conflicts of interest with regard to the work presented in this report

\section{References}

Agostinho AA, Pelicice FM, Gomes LC. Dams and the fish fauna of the Neotropical region: impacts and management related to diversity and fisheries. Braz J Biol 2008; 68:1119-1132.

Antunes RSP, Gomes VN, Prioli SMA, Prioli RA, Julio Jr HF, Prioli LM, Prioli, CS, Agostinho AA, Prioli AJ. Molecular characterization and phylogenetic relationships among species of the genus Brycon (Characiformes: Characidae) from four hydrographic basins in Brazil. Genet Mol Res 2010; 9:674-684.

Ashikaga FY, Orsi ML, Oliveira C, Senhorini JA, Foresti F. The endangered species Brycon orbignyanus: genetic analysis and definition of priority areas for conservation. Env Biol Fish 2015; 98:1-13.

Barroso RM, Hilsdorf AWS, Moreira HLM, Mello AM, Guimarães SEF, Cabello PH, Traub-Cseko YM. Identification and characterization of microsatellites loci in Brycon opalinus (Cuvier, 1819) (Characiforme, Characidae, Bryconiae). Mol Ecol Notes 2003; 3:297-298.

Bassam BJ, Caetano-Anollés G, Gresshoff PM. Fast and sensitive silver staining of DNA in polyacrylamide gels. Anal Biochem 1991; 196:80-83.

Caballero A, Rodríguez-Ramilo ST, Ávila V, Fernández J. Management of genetic diversity of subdivided populations in conservation programmes. Conserv Genet 2010; 11:409-419.

Coimbra MRM, Lima APS, Oliveira KKC, Severi W. Microsatellite assessment of the genetic diversity in indigenous populations of curimba (Prochilodus argenteus) in the São Francisco river (Brazil). Conserv Genet 2017; 18:1-11.

Excoffier L, Laval G, Schneider S. Arlequin ver. 3.0: an integrated software package for population genetics data analysis. Evol Bioinform Online 2005; 1:47-50.

Goudet J. FSTAT: A Program to Estimate and Test Gene Diversities and Fixation Indices (version 2.9.3.2). Department of Ecology and Evolution, Lausanne; 2002. URL: http://www2. unil.ch/popgen/softwares/fstat.htm.

Lima FCT. Subfamily Bryconinae, p. 174-181. In: Reis R.E. Kullander SO and Ferraris CJ. Check List of the Freshwater Fishes of South and Central America. Porto Alegre: EDIPUCRS; 2003. 734p.

Lopera-Barrero NM, Povh JA, Ribeiro RP, Gomes PC, Jacometo $\mathrm{CB}$, Lopes TS. Comparison of DNA extraction protocols of fish fin and larvae samples: modified salt $(\mathrm{NaCl})$ extraction. Cienc Investig Agrar 2008; 35:65-74.

Lopera-Barrero NM, Ribeiro RP, Povh JA, Sirol RN, Mangolin CA. Genetic evaluation of pacu (Piaractus mesopotamicus) natural populations and from the broodstocks of a stock enhancement program using microsatellite markers. Arq Bras Med Vet Zootec 2010; 62:954-963.

Lopera-Barrero NM, Alvarez CAR, Rodriguez-Rodriguez MP, Povh J, Vargas L, Streit Jr DP, Sirol RN, Ribeiro RP. Diversidade genética e paternidade de progênies de Brycon orbignyanus obtidas por diferentes sistemas reprodutivos. Semin Ciênc Agrár (Online) 2014; 35:541-554.

Lopera-Barrero MN, Povh JA, Sirol RN, Rodriguez-Rodriguez MP, Lima ECS, Poveda-Parra AR, Souza FP, Furlan P, Otonel RAA, Ribeiro RP. Genetic diversity of pacu and piapara broodstocks in restocking programs in the rivers Paraná and Paranapanema (Brazil). Semin Ciênc Agrár (Online) 2016; $37: 2365-2374$. 
Miller MP. TFPGA Version 1.3 - A Windows program for the analysis of allozyme and molecular population genetic data. Flagstaff: Department of Biological Science Northern Arizona University 1997.

Oliveira ABK. O rio Tietê: O processo histórico e sua importância para São Paulo. In: $1^{\circ}$ Simpósio Mineiro de Geografia, Alfenas. Anais. Alfenas: UFA 2014:271-285.

Panarari-Antunes RS, Prioli AJ, Prioli SMAP, Galdino AS, Julio Junior HF, Prioli LM. Genetic variability of Brycon orbignyanus (Valenciennes, 1850) (Characiformes: Characidae) in cultivated and natural populations of the upper Paraná River, and implications for the conservation of the species. Braz Arch Biol Technol 2011; 54:839-848.

Pereira AL. Impactos sócio-ambientais da Hidrelétrica do Funil na comunidade de Ponta Negra. Sinap Mult 2014; 3:135-146.

Povh JA, Ribeiro RP, Sirol RN, Streit Jr DP, Moreira HLM, Siewerdt F, Lopera-Barrero NM, Mangolin CA, Vargas L. Microsatellite analysis of the parental contribution of Piaractus mesopotamicus to the production of offspring in the semi-natural system of reproduction. Braz arch biol technol 2010; 53:389-396.

Reynalte-Tataje DA, Lopes CA, Ávila-Simas S, Garcia JRE and Zaniboni-Filho E. Artificial reproduction of neotropical fish: Extrusion or natural spawning? Nat Sci 2013; 5:1-6.

Ribeiro RP, Lopera-Barrero NM, Povh JA, Rodríguez-Rodríguez MP, Fornari DC, Baumgartner G, Baumgartner D, Souza FP,
Castro PL, Poveda-Parra AR. Genetic diversity of Salminus brasiliensis wild populations in downstream and upstream Cachoeira Branca, Verde River MS Brazil: A preliminary view. Semin Ciênc Agrár (Online) 2016; 37:507-516.

Rousset F. Genepop 2007: a complete re-implementation of the Genepop software for Windows and Linux. Mol Ecol Res 2008; 8:103-106.

Satake A, Araki H. Stocking of captive-bred fish can cause longterm population decline and gene pool replacement: predictions from a population dynamics model incorporating densitydependent mortality. Theor Ecol 2012; 5:283-296.

Souza FP, Castro PL, Goes ESR, Ribeiro RP, Santos SCA, Lima ECS, Murari PJF, Lopera-Barrero NM. Genetic variability of Prochilodus lineatus in artificial and semi-natural reproduction. Ital J Anim Sci 2018; 17:321-325.

Tamura K, Peterson D, Peterson N, Stecher G, Nei M, Kumar S. Mega 5: Molecular Evolutionary Genetics Analysis Using Maximum Likelihood, Evolutionary Distance, and Maximum Parsimony Methods. Mol Biol Evol 2011; 28:2731-2739.

Wright S. Evolution and genetics of population. Chicago: University of Chicago Press; 1978.

Yeh FC, Boyle TYZ, Xiyan JM. PopGene Version 131: Microsoft Window-based freeware for population genetic analysis. Alberta: University of Alberta and Center for International Forestry Research 1999. 